\title{
Article \\ Defect Study and Modelling of SnX3-Based Perovskite Solar Cells with SCAPS-1D
}

\author{
Md. Samiul Islam ${ }^{1}\left(\mathbb{D}\right.$, K. Sobayel $^{2, * \mathbb{D}}$, Ammar Al-Kahtani ${ }^{3} \mathbb{D}$, M. A. Islam $^{4} \mathbb{D}$, Ghulam Muhammad ${ }^{5} \mathbb{D}^{\text {, }}$ \\ N. Amin ${ }^{3, *(D)}$, Md. Shahiduzzaman 6 (D) and Md. Akhtaruzzaman $2, * \mathbb{D}$
}

1 Department of Electrical and Electronic Engineering, Southeast University, Dhaka 1207, Bangladesh; sami.seu@gmail.com

2 Solar Energy Research Institute, The National University of Malaysia, Bangi 43600, Malaysia

3 Institute of Sustainable Energy, Universiti Tenaga Nasional (@The National Energy University), Kajang 43000, Selangor, Malaysia; ammar@uniten.edu.my

4 Department of Electrical Engineering, Faculty of Engineering, University of Malaya,

Kuala Lumpur 50603, Malaysia; aminul.islam@um.edu.my

5 Department of Computer Engineering, College of Computer and Information Sciences, King Saud University, Riyadh 11461, Saudi Arabia; ghulam@ksu.edu.sa

6 Nanomaterials Research Institute, Kanazawa University, Kakuma, Kanazawa 920-1192, Japan; shahiduzzaman@se.kanazawa-u.ac.jp

* Correspondence: sobayel@ukm.edu.my (K.S.); nowshad@uniten.edu.my (N.A.); akhtar@ukm.edu.my (M.A.)

check for updates

Citation: Samiul Islam, M.; Sobayel, K.; Al-Kahtani, A.; Islam, M.A.; Muhammad, G.; Amin, N.;

Shahiduzzaman, M.; Akhtaruzzaman, M. Defect Study and Modelling of SnX3-Based Perovskite Solar Cells with SCAPS-1D. Nanomaterials 2021, 11, 1218. https://doi.org/10.3390/ nano11051218

Academic Editor: Julia Perez-Prieto

Received: 7 March 2021

Accepted: 8 April 2021

Published: 5 May 2021

Publisher's Note: MDPI stays neutral with regard to jurisdictional claims in published maps and institutional affiliations.

\section{Copyright: (c) 2021 by the authors.} Licensee MDPI, Basel, Switzerland. This article is an open access article distributed under the terms and conditions of the Creative Commons Attribution (CC BY) license (https:// creativecommons.org/licenses/by/ $4.0 /)$.

\begin{abstract}
Recent achievements, based on lead $(\mathrm{Pb})$ halide perovskites, have prompted comprehensive research on low-cost photovoltaics, in order to avoid the major challenges that arise in this respect: Stability and toxicity. In this study, device modelling of lead $(\mathrm{Pb})$-free perovskite solar cells has been carried out considering methyl ammonium tin bromide $\left(\mathrm{CH}_{3} \mathrm{NH}_{3} \mathrm{SnBr}_{3}\right)$ as perovskite absorber layer. The perovskite structure has been justified theoretically by Goldschmidt tolerance factor and the octahedral factor. Numerical modelling tools were used to investigate the effects of amphoteric defect and interface defect states on the photovoltaic parameters of $\mathrm{CH}_{3} \mathrm{NH}_{3} \mathrm{SnBr}_{3}$-based perovskite solar cell. The study identifies the density of defect tolerance in the absorber layer, and that both the interfaces are $10^{15} \mathrm{~cm}^{-3}$, and $10^{14} \mathrm{~cm}^{-3}$, respectively. Furthermore, the simulation evaluates the influences of metal work function, uniform donor density in the electron transport layer and the impact of series resistance on the photovoltaic parameters of proposed n- $\mathrm{TiO}_{2} / \mathrm{i}-\mathrm{CH}_{3} \mathrm{NH}_{3} \mathrm{SnBr}_{3} / \mathrm{p}-$ $\mathrm{NiO}$ solar cell. Considering all the optimization parameters, $\mathrm{CH}_{3} \mathrm{NH}_{3} \mathrm{SnBr}_{3}$-based perovskite solar cell exhibits the highest efficiency of $21.66 \%$ with the $V_{o c}$ of $0.80 \mathrm{~V}, J_{s c}$ of $31.88 \mathrm{~mA} / \mathrm{cm}^{2}$ and Fill Factor of $84.89 \%$. These results divulge the development of environmentally friendly methyl ammonium tin bromide perovskite solar cell.
\end{abstract}

Keywords: perovskite; $\mathrm{CH}_{3} \mathrm{NH}_{3} \mathrm{SnBr}_{3}$; solar cell; amphoteric defect; donor density; SCAPS

\section{Introduction}

An undisputed revolution in the development of photovoltaic technology was achieved by solar cells based on metal halide perovskites with the formula of $\mathrm{ABX}_{3}$ (where $\mathrm{A}$ is an organic or inorganic cation, $B$ is a lead or tin cation and $X$ is a halide anion). Over the past few years, the power conversion efficiency (PCE) of perovskite solar cells (PVSCs) has increased rapidly from $3.9 \%$ to a certified $22.7 \%$ [1-5]. The remarkable increase in PCE is attributed to the supreme optoelectronic properties, such as high absorption coefficient $\left(\sim 10^{5} \mathrm{~cm}^{-1}\right)$, low exciton binding energy $(\sim 20 \mathrm{meV})$, and relatively long diffusion duration of the carrier $(>1 \mu \mathrm{m})$ [6-9]. In addition, perovskite structure engineering from the simple methylammonium lead iodide $\left(\mathrm{CH}_{3} \mathrm{NH}_{3} \mathrm{PbI}_{3}\right)$ perovskite to the new mixed-cation and mixed-anion halide perovskite materials also results in high efficiency [5,10-12]. Despite the rapid development, to achieve stability and meet the Shockley-Queisser Limit (SQL), which is $\sim 30.5 \%$ PCE for a single Methylammonium Lead Iodide $\left(\mathrm{MAPbI}_{3}\right)$-based junction 
cell, the overall PCE of perovskite-based solar cells is still far away. Again, it is already reported that NiO-based inverted structure device can demonstrate superior stability than planner structure [13]. Therefore, it is particularly important, not only to minimize environmental toxicity by removing $\mathrm{Pb}$ in the perovskite composition, but also to achieve stability by compositional engineering without compromising photovoltaic efficiency to facilitate the commercialization of PVSCs [14-16]. The partial substitution or full replacement of $\mathrm{Pb}$ with comparatively less toxic tin (Sn) is an obvious choice among the many approaches investigated because of the similarity in their ionic radii $\left(\mathrm{Sn}^{2+}: 0.93 \AA\right.$ vs. $\mathrm{Pb}^{2+}: 1.20 \AA$ ) and electronic configurations that could theoretically retain the exceptional semiconducting properties of $\mathrm{APbX}_{3}$ [14]. In comparison to their pristine $\mathrm{Pb}$-based counterparts, the synthesis of Sn-based perovskites promotes the recognition of lower band gap (Eg) perovskites [17-20]. Again, researchers found that the tuning of halide ions in the perovskite structure can lead to higher stability of the device. In this respect, several other attempts have been made to build efficient low Eg PVSCs based on Sn [10,12,14]. Nevertheless, there are still many problems that hinder the production of Sn-based PVSC with bromine $(\mathrm{Br})$ as cation. In order to develop a non-toxic, highly efficient and stable PVSC, this article proposes a new absorber layer (Figure 1) of perovskite- $\mathrm{CH}_{3} \mathrm{NH}_{3} \mathrm{SnBr}_{3}$.

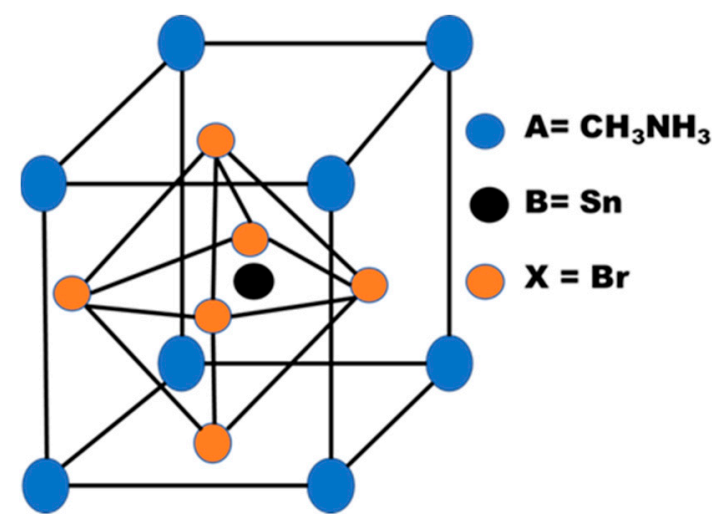

Figure 1. Proposed Perovskite Structure $\mathrm{CH}_{3} \mathrm{NH}_{3} \mathrm{SnBr}_{3}$.

Hence, a numerical simulation has been performed through SCAPS-1D software on a proposed new perovskite structure to validate its design and to evaluate its performance for commercial implementation. Moreover, amphoteric defect state of the absorber, defect tolerance at interfaces and electrical properties of the solar cell device have also been investigated.

\section{Theoretical Concept}

In nature, the perovskite structure $\left(A B X_{3}\right)$ is symmetric, where $A$ is greater than $X$ (Figure 1). $X$ can be substituted with various $\mathrm{O}, \mathrm{Cl}, \mathrm{Br}, \mathrm{I}$, and $\mathrm{S}$ elements throughout the composition. Atom placements in the three-dimensional (3D) structure are primarily considered to be connected to the stability required for a chemical charge neutralization process [21]. A key requirement for perovskite minerals is that, while the basic structure appears plain, structural distortion characteristics are quite different [22]. Due to this, the solar cell researchers have been investigating Tin (Sn)-based perovskite solar cell as an alternative, where the lead is substituted by tin and modified material compositional structure looks like $\mathrm{ASnX}_{3}$. The primary benefits of tin-based perovskite solar cells are that they are lead-free and can help tune the active layer's bandgap further. Additionally, by reducing the acceptor doping the concentration of the active layer, the efficiency of the tin-based solar cell can be improved.

Another noteworthy point is that the incorporation of suitable cations to form perovskite structure are estimated based on two important parameters: Goldschmidt tolerance factor $(t)$, and the octahedral factor $(\mu)$. Tolerance factor $(t)$ is the function of iconic radii 
and a dimensionless parameter. Octahedral factor $(\mu)$ demonstrates the relation between ionic radii of $B$ cation and $X$ anion [23]. They are expressed as following equations,

$$
\begin{gathered}
t=\frac{r_{A}+r_{X}}{\sqrt{2}\left(r_{B}+r_{X}\right)} \\
\mu=\frac{r_{B}}{r_{X}}
\end{gathered}
$$

where $r_{A}$ and $r_{B}$ represents the ionic radii of two big size cations $A$ and $B$, and $r_{X}$ represents the ionic radius of smaller halide anion. The tolerance factor $(t)$ should fall within the range of 0.8-1.0 for the formation of robust perovskite structures. The variety of octahedral factor $(\mu)$ must be limited within $0.44-0.72$ to form a stable $B X_{6}$ octahedron for $B$ cation and $X$ anion. [24] Goldschmidt's tolerance factor $(t)$ has played a major role in the development of perovskites [25] and has also been used to develop/synthesize new hybrid organicinorganic stable perovskite structures by formulating the composition of perovskites. The tolerance factor can be tailored to the stable perovskite range by combining different $A / B$ cations and $X$ anions in a particular composition [26-29].

In our proposed perovskite structure $\left(\mathrm{CH}_{3} \mathrm{NH}_{3} \mathrm{SnBr}_{3}\right), r_{A}, r_{B}$ and $r_{X}$ values are 217, 110 and 181 pm respectively [30]. From Equation (1) and Equation (2), it is found that tolerance factor $(t)$ and octahedral factor $(\mu)$ of proposed structure are 0.967 , and 0.607 respectively, both are within the ideal range of stable perovskite structure. Hence, it can be said that the proposed perovskite structure $\left(\mathrm{CH}_{3} \mathrm{NH}_{3} \mathrm{SnBr}_{3}\right)$ can be an ideal candidate for $\mathrm{Pb}$ free highly efficient stable perovskite solar cell.

\section{Device Structure and Simulation Parameters}

Besides the experimental study, the simulation environment provides a power full tool to better understand about the physical behavior of different optoelectronic properties of any solar cell. In relation to the electrical simulation, the software like the Solar Cell Capacitance Simulator (SCAPS-1D) [31-38] was used, which basically works on two basic semiconductor equations, including, the Poisson equation and the continuity equation of electrons and holes under steady-state condition.

In this study, a simulation based on hypothetical research has been performed to sketch the performance of lead $(\mathrm{Pb})$ free Tin $(\mathrm{Sn})$ based perovskite material which acts as an absorber layer, sandwiched by two transport layers- $\mathrm{TiO}_{2}$, and $\mathrm{NiO}$ respectively. The architecture of the device is $\mathrm{FTO} / \mathrm{TiO}_{2} / \mathrm{CH}_{3} \mathrm{NH}_{3} \mathrm{SnBr}_{3} / \mathrm{NiO}$, where FTO acts as the Transparent Conductive Oxide (TCO), $\mathrm{TiO}_{2}$ and $\mathrm{NiO}$ acts as the ETL, and HTL materials, respectively. The schematic structure and energy band diagram of this work are given below in Figure 2.

For the incident radiation, a regular AM1.5 G illumination spectrum $\left(1000 \mathrm{Watt} / \mathrm{m}^{2}\right.$; $\mathrm{T}=300 \mathrm{~K}$ ) was employed. Standard layer thickness of were acquired from the various recorded articles [32-34]. In order to assess the consequence of defect densities subsisting on material boundaries (the perovskite/ETL and perovskite/HTL boundaries), a very thin interface defect layer of $10 \mathrm{~nm}$ was used. Additionally, in this simulation, the amphoteric inherent defect model is used to reproduce the defects of PSC, where the density of the defect in the active layer varied. Gaussian energy distribution with a characteristic energy of $0.1 \mathrm{eV}$ was considered for all defect states. The thermal velocity of the electrons and holes of $1 \times 10^{7} \mathrm{~cm} / \mathrm{s}$ were taken during simulation. This simulation software was used to investigate the different performance metrics Fill factor $(F F)$, short-circuit current density $(J s c)$, open-circuit voltage (Voc), efficiency $(\eta)$ of a perovskite based solar cell [39]. Table 1 summarizes the material parameters that were used in this simulation. 

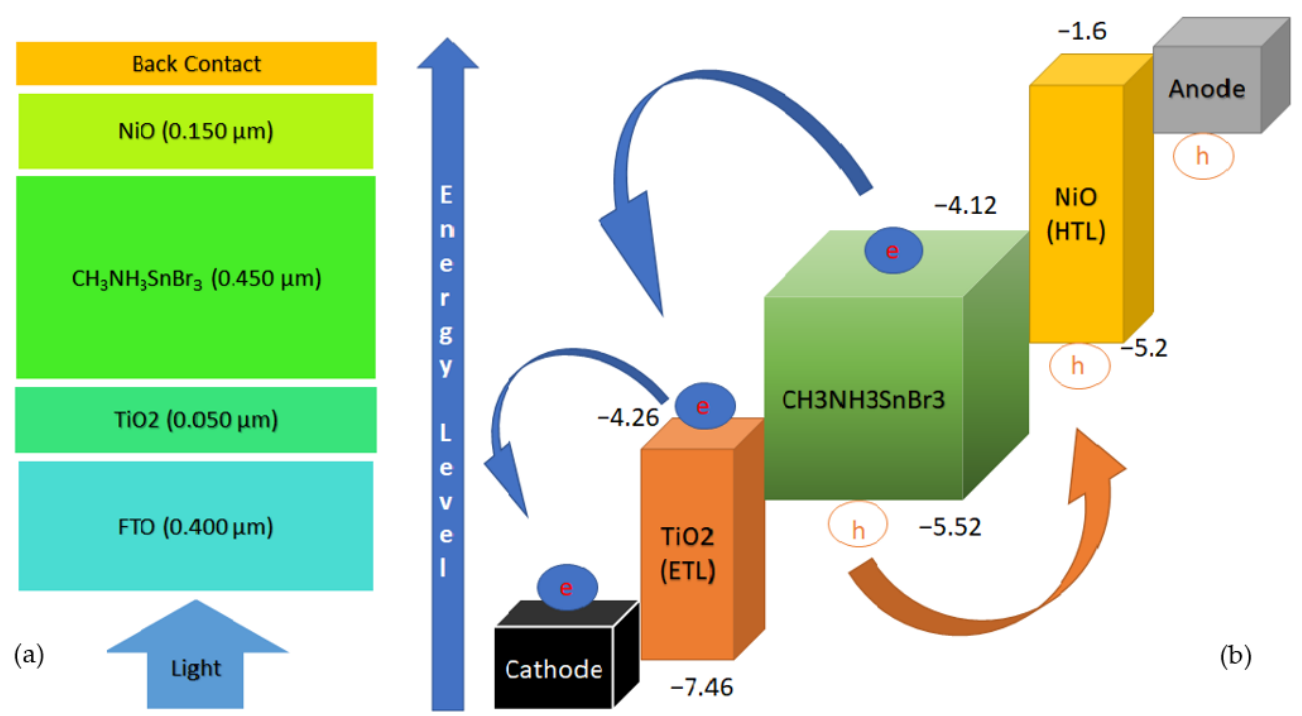

Figure 2. (a) Schematic diagram of proposed solar cell; and (b) energy band diagram of $\mathrm{CH}_{3} \mathrm{NH}_{3} \mathrm{SnBr}_{3}$ solar cell.

Table 1. Simulation Parameter used in SCAPS-1D.

\begin{tabular}{ccccc}
\hline Parameter & FTO [35,36] & $\mathbf{T i O}_{2}[35,37]$ & $\mathbf{C H}_{3} \mathbf{N H}_{3} \mathbf{S n B r}_{3}[30,37]$ & $\mathbf{N i O}[34,37]$ \\
\hline Thickness $(\mu \mathrm{m})$ & 0.4 & 0.05 & 0.5 & 0.15 \\
$E_{g}(\mathrm{eV})$ & 3.5 & 3.26 & 1.3 & 3.6 \\
$\chi(\mathrm{eV})$ & 4.0 & 4.2 & 4.17 & 1.8 \\
$\varepsilon$ & 9.0 & 10.0 & 10.0 & 11.7 \\
$N_{C}\left(\mathrm{~cm}^{-3}\right)$ & $2.2 \times 10^{18}$ & $2.2 \times 10^{18}$ & $2.2 \times 10^{18}$ & $2.5 \times 10^{20}$ \\
$N_{v}\left(\mathrm{~cm}^{-3}\right)$ & $1.8 \times 10^{18}$ & $1.8 \times 10^{18}$ & $1.8 \times 10^{18}$ & $2.5 \times 10^{20}$ \\
$\mu_{n}\left(\mathrm{~cm}^{2} / \mathrm{Vs}\right)$ & 20 & 20 & 1.6 & 2.8 \\
$\mu_{p}\left(\mathrm{~cm}^{2} / \mathrm{Vs}\right)$ & 10 & 10 & 1.6 & 2.8 \\
$N_{D}\left(\mathrm{~cm}^{-3}\right)$ & $1 \times 10^{19}$ & $1 \times 10^{17}$ & $1 \times 10^{13}$ & 0 \\
$N_{A}\left(\mathrm{~cm}^{-3}\right)$ & 0 & 0 & $1 \times 10^{13}$ & $3 \times 10^{18}$ \\
\hline
\end{tabular}

\section{Results and Discussion}

\subsection{Effect of Amphoteric Defect Density in the Absorber Layer}

The $\mathrm{CH}_{3} \mathrm{NH}_{3} \mathrm{SnBr}_{3}$ layer exhibits various forms of conductivity based on the Sn and halide molecules deposition properties. Moreover, $\mathrm{Sn}^{2+}$ cataion is very prone to oxidation during the process of fabrication, which attributes defects inside the perovskite structure $[35,40]$. In order to determine the electron-hole diffusion length and open circuit voltage (Voc), defect properties in the solar cell absorber layer play a significant role. The definition of amphoteric defects was initially familiar with the clarifying effects on the properties of semiconducting materials of native (or inherent) defects. More recently, the principle of amphoteric native defects has been used in PSC devices to regulate the inclusion of defects in compound semiconductors, such as $\mathrm{CH}_{3} \mathrm{NH}_{3} \mathrm{PbX}_{3}$ [41]. In this work, amphoteric defect has been considered above the Ev of the absorber layer with uniform energetic distribution where defect state has been varied from $10^{13} \mathrm{~cm}^{-3}$ to $10^{17} \mathrm{~cm}^{-3}$. The details have been given at Appendix A (Table A1). Figure 3 exhibits the influence of amphoteric defect on solar cell parameters of proposed $\mathrm{CH}_{3} \mathrm{NH}_{3} \mathrm{SnBr}_{3}$ solar cell. It is found that $V o c$ decreases gradually with the rise of defect density (Figure 3a). On the other hand, we did not observe any significant changes in short circuit current density (Jsc) and Fill Factor $(F F)$ (Figure 3b,c) until density of defect state increased above $10^{16} \mathrm{~cm}^{-3}$. However, both parameters exhibited declining behavior beyond this critical value, which supports the theoretical aspect of the device performance. With the increase of defect densities, the unwanted recombination rate increased as the defects created the dangling bonds, which act like the trap state for the photo-generated charge carriers. This is the reason why the 
short circuit current decreased, which is eventually responsible for lowering the Fill Factor $(F F)$ of the device. The device efficiency also dropped significantly from $24.5 \%$ to $16.17 \%$, when amphoteric defect density increased to $10^{15}$ to $10^{16} \mathrm{~cm}^{-3}$. Such a sharp fall in solar cell performance can be attributed to the increasing number of recombination.
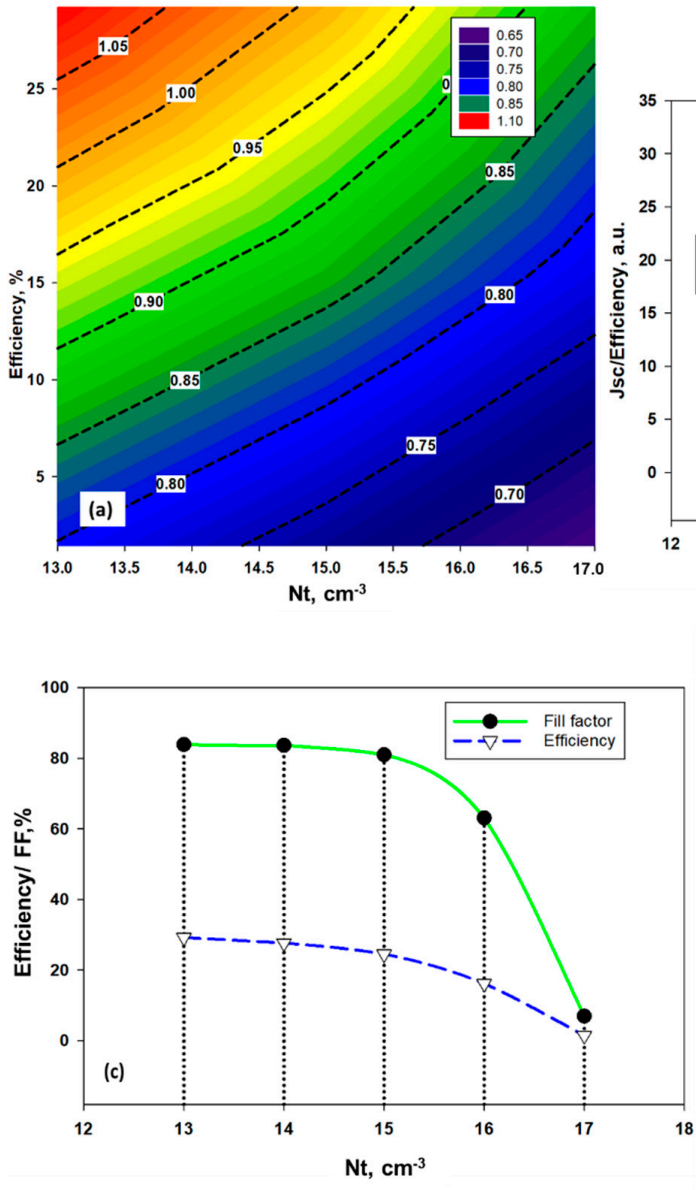
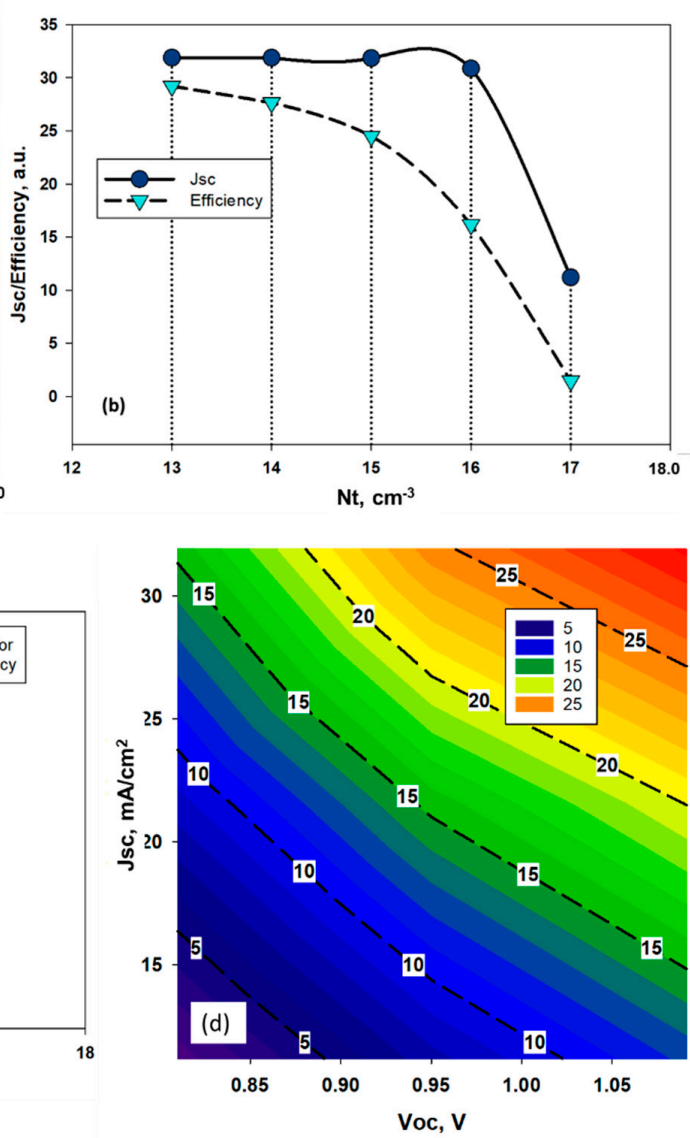

Figure 3. Effects of the variation of, (a) Efficiency and Voc, (b) Jsc and efficiency, and (c) $F F$ and efficiency w.r.t. amphoteric defect density $\mathrm{Nt}$, (d) relationship between $V o c$ and $J s c$ w.r.t efficiency for different amphoteric defect states in $\mathrm{CH}_{3} \mathrm{NH}_{3} \mathrm{SnBr}_{3}$.

Figure 3d shows the typical relationship between Voc, Jsc and efficiency for different state of amphoteric defect densities. It was found that the decrease in efficiency is mainly due to the fall in Jsc. The defects act like the recombination centre of the photogenerated carriers, limiting the short circuit current $(J s c)$. Therefore, the defect tolerance for the tin (Sn)-based halide perovskite is around $1 \times 10^{15} \mathrm{~cm}^{-3}$.

\subsection{Effect of Interface Defect States}

The impact of defect states in both the interfaces of Perovskite Solar Cell (PSC), $\mathrm{TiO}_{2} / \mathrm{MASnBr}_{3}$ and $\mathrm{MASnBr}_{3} / \mathrm{NiO}$, have been studied in detail. At the ETL/Perovskite interface, density of defect states has varied from $10^{12} \mathrm{~cm}^{-3}$ to $10^{20} \mathrm{~cm}^{-3}$ where the position of the defect state was considered at the above of $E_{v}$ with gaussian energetic distribution. It has been noted that $V_{o c}$ and efficiency decreases sharply (Figure 4a) from $0.99 \mathrm{~V}$ to $0.89 \mathrm{~V}$, and $26.75 \%$ to $19.75 \%$, respectively, when the density of the defect state in the interface reached $10^{14} \mathrm{~cm}^{-3}$. However, we did not find a notable observation for Jsc and $F F$, though both decreases (Figure $4 \mathrm{~b}, \mathrm{c}$ ) with the increase of defect state density. Figure $4 \mathrm{~d}$ expresses the correlation between $V_{o c}, J_{s c}$ and defect states in the ETL/Perovskite interface. It can be observed that increments in the level of defect state mainly impact the open circuit voltage rather than short circuit current. Therefore, a change in $V_{o c}$ is mainly attributable 
to the drop in the efficiency of the device. Hence, defect tolerance at $\mathrm{TiO}_{2} / \mathrm{MASnBr}_{3}$ can be figured up to $10^{14} \mathrm{~cm}^{-3}$ as beyond this level efficiency of $\mathrm{CH}_{3} \mathrm{NH}_{3} \mathrm{SnBr}_{3}$ solar cell deteriorates to a great extent.
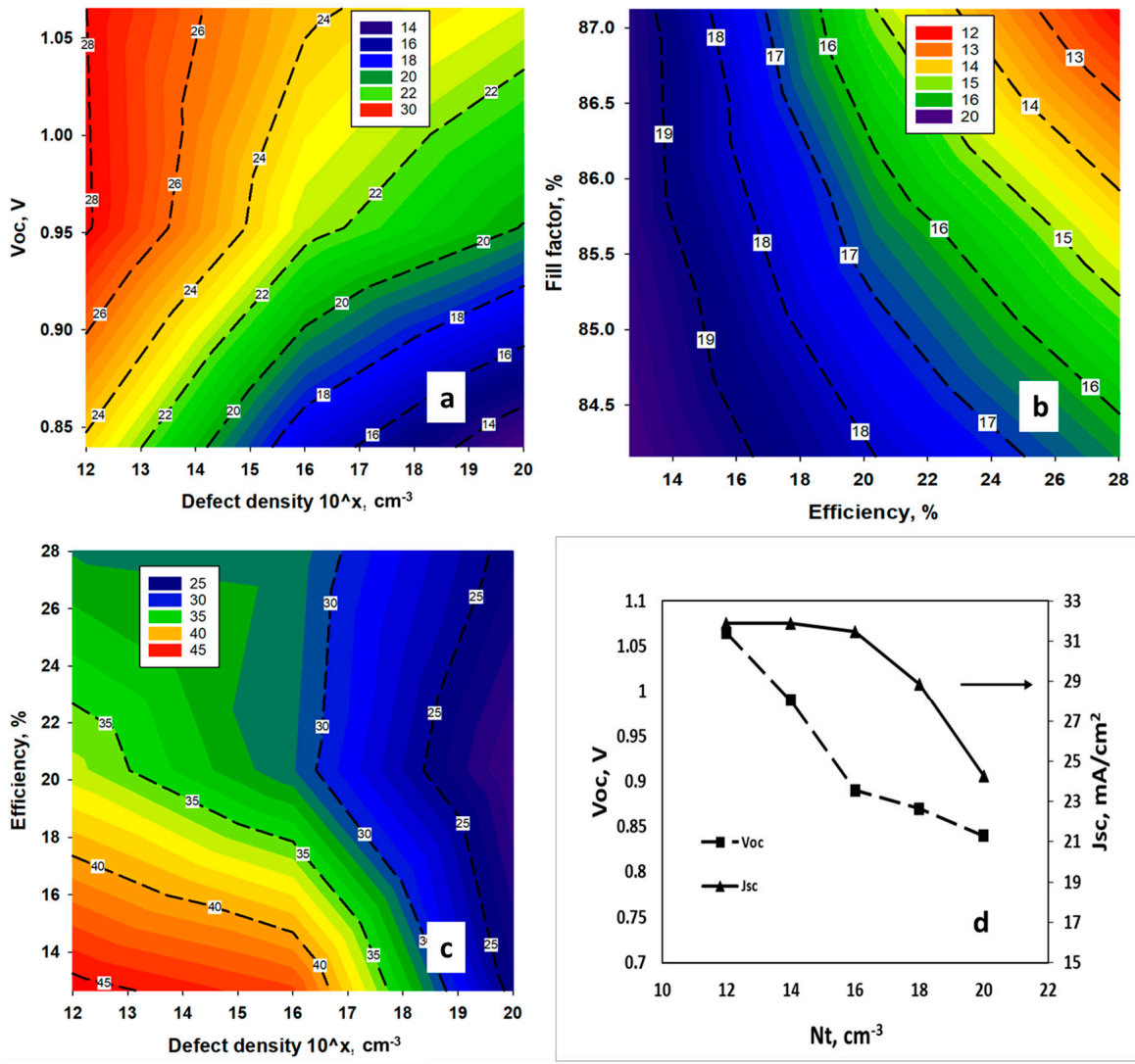

Figure 4. Effects of the variation of, (a) efficiency and Voc, (b) Jsc and efficiency and (c) FF and efficiency w.r.t. $\mathrm{TiO} 2 /$ Perovskite interface defect density $\mathrm{Nt}$, (d) relationship between $V o c$ and Jsc w.r.t various interface defect density in $\mathrm{ETL} / \mathrm{CH}_{3} \mathrm{NH}_{3} \mathrm{SnBr}_{3}$ interface.

On the other hand, at the HTL/Perovskite interface, density of defect states has been varied from $10^{13} \mathrm{~cm}^{-3}$ to $10^{18} \mathrm{~cm}^{-3}$ where position of defect state has been considered at the middle of the interface with uniform energetic distribution. To determine the efficiency of the overall structure, the defect densities of the whole transport layer and the perovskite absorber play a pivotal role. It has been revealed that Voc decreases steadily (Figure 5a) with the increase of defect density at HTL/Perovskite interface. In the case of Jsc, it decreased with the increase in the defect state (Figure 5b), and exhibited a sharp fall of current $\left(24.18 \mathrm{~mA} / \mathrm{cm}^{2}\right.$ to $\left.19.68 \mathrm{~mA} / \mathrm{cm}^{2}\right)$ when the density of the defect state increased from $10^{15}$ to $10^{16} \mathrm{~cm}^{-3}$. However, the change in fill factor with the increase of defect density (Figure 5c) was very negligible. However, the efficiency of the solar cell showed a steady decrease from $23.6 \%$ to $18.49 \%$ up to the defect density range $10^{15} \mathrm{~cm}^{-3}$. After that, there was a sharp decrease in efficiency of the cell with the increasing values of defect state. Figure $5 \mathrm{~d}$ represents typical relationship between $J s c$ and Voc w.r.t defect density. The density of the defect state in the HTL/Perovskite interface was observed to primarily affect the short-circuit current than open circuit voltage when density of defect becomes over $10^{14} \mathrm{~cm}^{-3}$. The interface between the perovskite and $\mathrm{NiO}$ layer plays a vital role damaging the short circuit current. It. The critical issue regarding $\mathrm{NiO}$ thin film is the presence of surface defects acting as trap states in the solar cell structure, which seriously affects the charge carrier transfer since charge extraction only occurs at the interfaces. As a result, detrimental hysteresis and light soaking takes place due to charge recombination [42]. 
In $\mathrm{NiO}$ films, the defects are characteristically existing in the form of hydroxyl groups originating from the oxygen deficiency or unconverted $\mathrm{Ni}(\mathrm{OH})_{2}$ [43-46]. Hence, we can determine that tolerance of defect state for $\mathrm{MASnBr}_{3} / \mathrm{NiO}$ interface is $10^{14} \mathrm{~cm}^{-3}$.
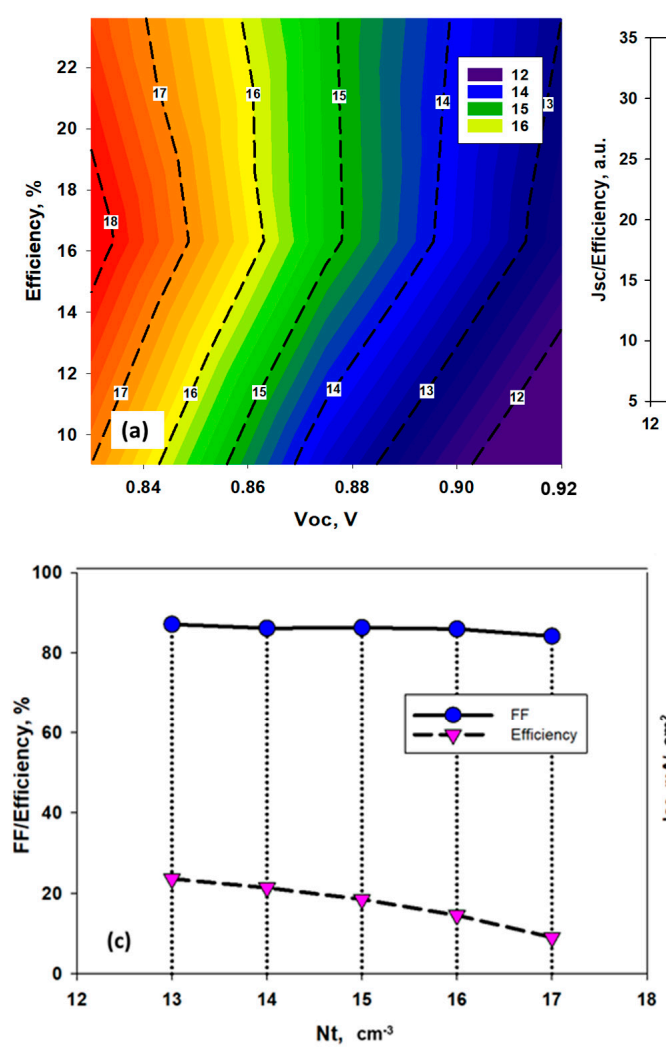
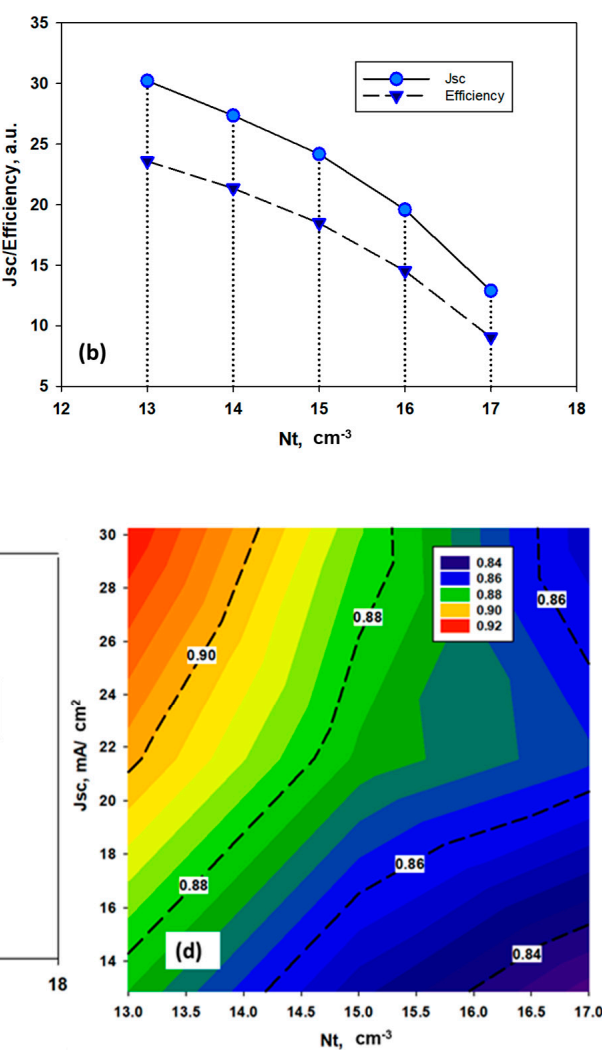

Figure 5. Effects of the variation of (a) Efficiency and Voc, (b) JSC and efficiency and (c) FF and efficiency w.r.t. $\mathrm{NiO} /$ Perovskite interface defect density $\mathrm{Nt}(\mathrm{d})$ relationship between $V o c$ and Jsc w.r.t various interface defect density in $\mathrm{NiO} / \mathrm{CH}_{3} \mathrm{NH}_{3} \mathrm{SnBr}_{3}$ interface.

\subsection{Metal Work Function}

The work function of a metal is the amount of energy or photons required to extract an electron from the metal surface [47]. It was reported that higher values of work function lead to increased solar cell efficiency $[48,49]$. This is attributed to the fact that the barrier height of the majority carrier decreases with the increase in hte work function value, which eventually makes contact more ohmic type. Therefore, as the metal's work function increases, both the open circuit voltage and cell efficiency also increase. Au and $\mathrm{Pt}$ are the most commonly used back contact metal in solar cell but both are expensive. In this work, simulations were performed to identify a suitable earth abundant metal for using as back contact in the proposed device structure (Figure 2). The parameters for the contact materials used for this simulation are shown in Table $2[47,49]$. The efficiency of the solar cell $\mathrm{CH}_{3} \mathrm{NH}_{3} \mathrm{SnBr}_{3}$ (without defects) versus various metals (metal working function) used in the back contact of the system structure is shown in Figure 6 and Appendix B Table A2.

Table 2. Metal work function for different materials.

\begin{tabular}{cccccc}
\hline Back Contact Metal & $\mathbf{A u}$ & $\mathbf{A g}$ & $\mathbf{F e}$ & $\mathbf{C u}$ & Cu Doped C \\
\hline Metal work function $(\mathrm{eV})$ & 5.1 & 4.7 & 4.8 & 4.6 & 5.0 \\
\hline
\end{tabular}




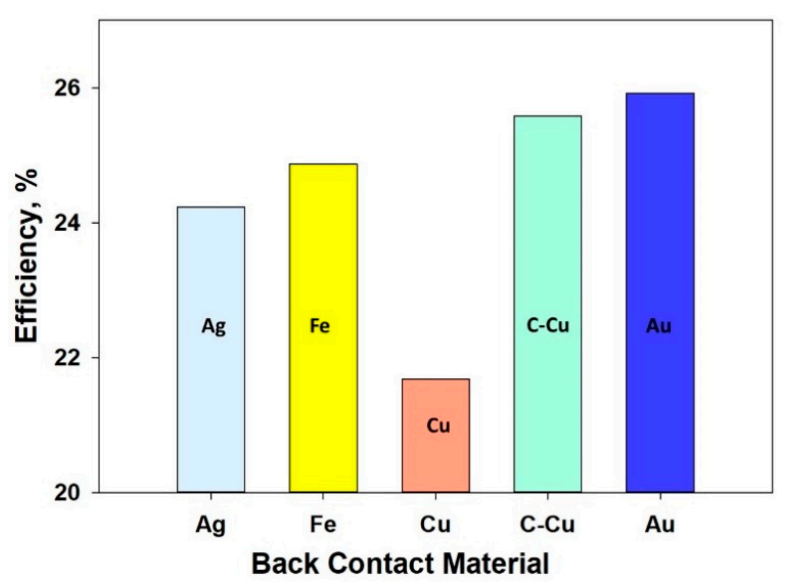

Figure 6. Solar cell efficiency w.r.t. different back contact metal.

\subsection{Effect of Doping Density of the $\mathrm{TiO}_{2} / \mathrm{MASnBr}_{3}$ Heterojunction}

Mott-Schottky (MS) is a well-known and effective instrument used assessing the builtin potential $\left(\mathrm{V}_{\mathrm{bi}}\right)$ - the difference between the functions of electrode operation [50] and the doping level of a device. MS theory is mainly based on the p-n junction properties [51], but it is also used in organic devices as well [52-54]. In the MS plot, slope of $1 / \mathrm{C}^{2}(\mathrm{~V})$ interprets as a concentration of occupied trapping centers [53-55] and the $x$-axis intercept is usually representing the $V_{b i}$ of organic semiconductor devices. Although the obtained values are lower than expected from the difference of the electrode work functions [56-58]. In reverse polarization, the capacitance of the system is the sum of the capacitance of the junction and the capacitance of the contact (for metal/ $\mathrm{TiO}_{2}$ interface) [47,57]. The $\mathrm{C}-\mathrm{V}$ characteristics and Mott-Schottky plot analysis of proposed solar cells were simulated in Figure 7a,b as a function of the $\mathrm{TiO}_{2}$ structure's shallow uniform donor density $\left(\mathrm{N}_{\mathrm{d}}\right)$. The concentration of donor density $\left(\mathrm{N}_{\mathrm{d}}\right.$ ) varied in the range from $10^{14} 1 / \mathrm{cm}^{3}$ to $10^{18} 1 / \mathrm{cm}^{3}$ keeping other variables as constant. It has been observed (Figure $7 \mathrm{a}$ ) that the capacitance increases gradually with the applied voltage and increased sharply at higher voltage and reached a maximum when $N_{d}$ is $10^{18} 1 / \mathrm{cm}^{3}$. From Figure $7 \mathrm{a}$, it is clear that, at zero bias, this structure is fully depleted, but when the forward bias is applied, around $0.5 \mathrm{~V}$, the depletion width shrinks to approximately equal to the thickness of the absorber layer. Therefore, capacitance increases with further increase in forward bias voltage, and behave according to Mott-Schottky relationship. It was already reported that the current is significantly lesser than the saturation current at low voltages, but the current was restricted to the saturation current at the contact at high voltages [59]. The lower value of the built-in potential (Vbi), obtained from the Mott-Schottky plot under illumination, can be ascribed to the capacitance originating from the photogenerated charge carriers that can build up in the low-mobility materials, even at reverse bias [60]. When doping concentration increases, charge accumulation increases at the interface and the capacitance value will also rise. Eventually the thickness of the depletion layer/space charge layer decreases, which eventually decrease the built-in potential (Vbi), according to the conventional capacitance equation:

$$
C=\epsilon_{0} \frac{A}{d} .
$$

This leads to decrease in the voltage at the interface of metal $/ \mathrm{TiO}_{2}$. Figure $7 \mathrm{~b}$ represents the determination of built-in potential $\left(\mathrm{V}_{\mathrm{bi}}\right)$ Mott-Schottky relation at $1 / C^{2}=0$ on the potential axis [61]. The built-in potential $\left(\mathrm{V}_{\mathrm{bi}}\right)$ has been found to increase from $0.69 \mathrm{~V}$ to $0.77 \mathrm{~V}$ with the increase of $\mathrm{Nd}$. 
Flat band potential at the interface is an important parameter in designing solar cell. Larger flat band potential makes it easier for the charge carriers to transfer at the interfacewhich can be obtained from the Mott-Schottky plot using the following equation,

$$
\frac{1}{C^{2}}=\left[\frac{2}{q \epsilon_{s} \epsilon_{0} N_{d}}\right]\left[V_{a p p-V_{F B}-\left(\frac{K_{B} T}{q}\right)}\right]
$$

where $q$ is charge on the carriers, $\epsilon_{s}$ the permittivity of semiconductor, $\epsilon_{0}$ the permittivity of free space, $\mathrm{N}_{\mathrm{d}}$ the donor density, $\mathrm{V}_{\mathrm{FB}}$ the flat band potential, $K_{B}$ the Boltzmann's constant and $T$ the temperature of operation [62].

When the donor concentration increases the band bending increases, which lower the accumulation of charge carriers at the depletion zone and capacitance value decreases.
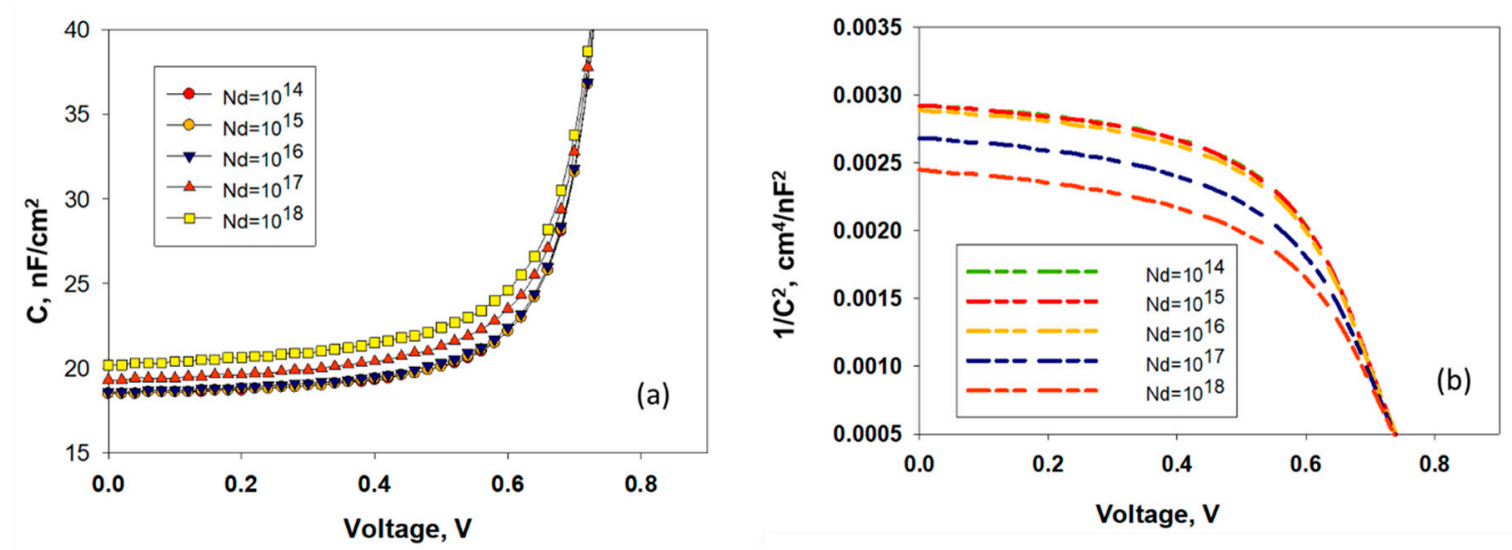

Figure 7. (a) C-V characteristics, and (b) Mott-Schottky plot attained using SCAPS as a function of shallow donor density $\left(\mathrm{N}_{\mathrm{d}}\right)$.

\subsection{Optimized Device and Effects of Series Resistances on the Performance of the Solar Cell}

Non-ideality in a solar cell is an established reality now, which hinders the performance of the cell. There are several factors responsible for this, and one of them being parasitic resistances. Both series (Rs) and shunt resistances reduce the output of a solar cell. Figure 8 represents the equivalent circuit of a solar cell. Prior to analyzing the effects of series resistance, we have performed the simulation based on defect tolerances, optimized metal work function (MWF) and ideal $\mathrm{N}_{\mathrm{d}}$ that has been investigated above. It is found that proposed device exhibits $21.66 \%$ efficiency with $V_{o c}=0.80 \mathrm{~V}, J_{s c}=31.88 \mathrm{~mA} / \mathrm{cm}^{2}$ and $F F=84.89 \%$ (Figure 9a).

In the perovskite solar cells, basically a p-i-n or n-i-p structure is considered. Rs in solar cell mainly exists in the contacts or interfaces: resistance at HTL/perovskite interface, resistance at Electron Transport layer (ETL)/perovskite interface and resistance of the top and rear metal contacts. Moreover, when solar cells are exposed to climate, in practical applications inside a module, the thermomechanical fatigue or cracks develop in the solder bonds depending on the climatic conditions. These cracks lead to increase the Rs of solar cell.

It is already reported that increase in Rs affects directly to the drop of Fill Factor drop due to solder bond degradation, whereas the $J_{s c}$ drop is attributed to the optical transmission loss caused by the encapsulant discoloration [63]. The simulation results on varying series resistances $\left(\mathrm{R}_{\mathrm{s}}\right)$ on the proposed $\mathrm{CH}_{3} \mathrm{NH}_{3} \mathrm{SnBr}_{3}$ based solar cell structure is shown in Table 3 and figures are shown in Appendix C (Figure A1). 


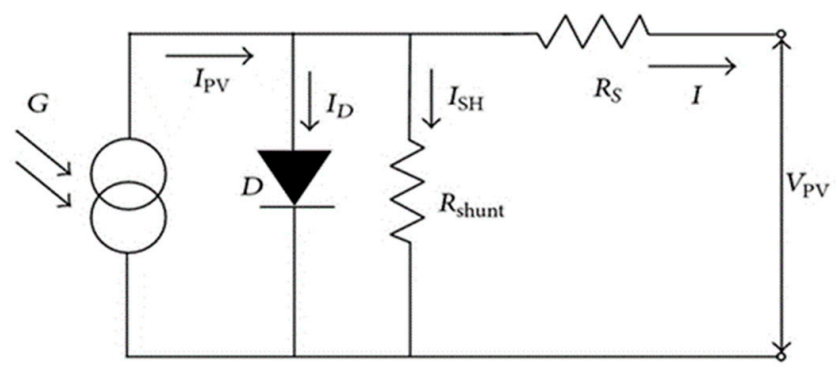

Figure 8. Equivalent circuit of a solar cell.
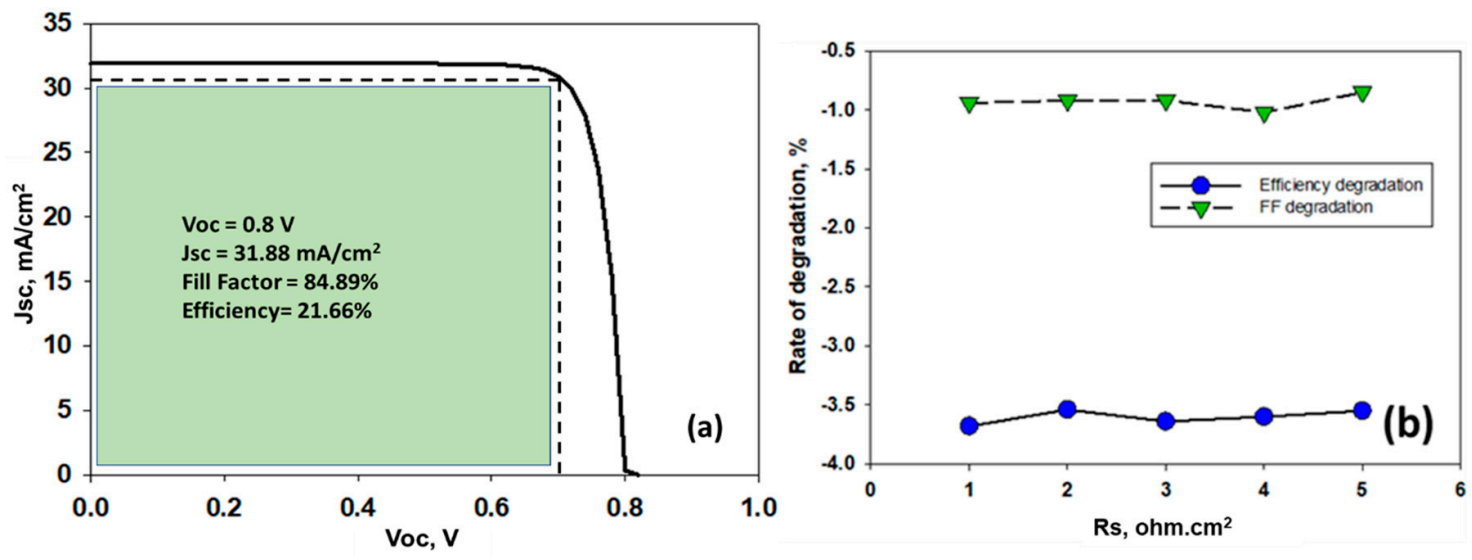

Figure 9. (a) Optimized $\mathrm{CH}_{3} \mathrm{NH}_{3} \mathrm{SnBr}_{3}$ based solar cell performance, (b) rate of change of $F F$ and efficiency w.r.t Rs.

Table 3. Effects of series resistance on photovoltaic parameters of $\mathrm{CH}_{3} \mathrm{NH}_{3} \mathrm{SnBr}_{3}$ based solar cell.

\begin{tabular}{|c|c|c|c|c|}
\hline Resistance, Ohm.cm ${ }^{2}$ & $V_{o c}, \mathrm{~V}$ & $J_{s c}, \mathrm{~mA} / \mathrm{cm}^{2}$ & $F F, \%$ & Efficiency, \% \\
\hline 0 & 0.814 & 31.88 & 84.89 & 21.66 \\
\hline 1 & 0.814 & 31.88 & 81.21 & 20.72 \\
\hline 2 & 0.814 & 31.88 & 77.67 & 19.8 \\
\hline 3 & 0.814 & 31.87 & 74.03 & 18.88 \\
\hline 4 & 0.814 & 31.80 & 70.43 & 17.86 \\
\hline 5 & 0.814 & 31.78 & 66.88 & 17.01 \\
\hline
\end{tabular}

It has been observed that the increase in series resistance adversely affects the Fill Factor, and once Rs is remarkably high, it slightly affects the $J_{s c}$. These findings are completely agreement with the reported literature. It has been observed that FF degrades almost 3.6\% with each $0.01 \Omega$ increase in Rs, which is a little higher than conventional Si (approximately $2.5 \%$ per $0.01 \Omega$ increase in Rs) solar cell. However, it is encouraging that while FF degrades at $3.6 \%$, but efficiency degrades much lower rate-only at $0.857 \%$ with $0.01 \Omega$ increase in Rs.

\section{Conclusions}

In summary, this article unveiled a $\mathrm{Pb}$ free perovskite solar cell by non-toxic $\mathrm{Sn}$ based $\mathrm{CH}_{3} \mathrm{NH}_{3} \mathrm{SnBr}_{3}$ and analyzed with SCAPS 1D simulation software. The model was initially verified by Goldschmidt tolerance factor and the octahedral factor, and found to be in the ideal range of stable perovskite structure. As a native type defect, amphoteric defect is likely to form during fabrication process, thereby reducing its concentration to $10^{15} \mathrm{~cm}^{-3}$ can lead to a highly efficient solar cell. Again, controlling the defects at the interfaces are most critical factor for high efficiency of solar cells, and scaling down to as low as $10^{14} \mathrm{~cm}^{-3}$ in both the interfaces can significantly increase the PCE of the device. The study also suggests that the efficiency of $n-\mathrm{TiO}_{2} / \mathrm{i}-\mathrm{CH}_{3} \mathrm{NH}_{3} \mathrm{SnBr}_{3} / \mathrm{p}-\mathrm{NiO}$ solar cells can increase by replacing costly $\mathrm{Au}$ with $\mathrm{Cu}$ doped $\mathrm{C}$ as back contact material, and by selecting 
the optimal density state of the $\mathrm{n}-\mathrm{TiO}_{2}$ layer. Again, the study portrays that while $F F$ of proposed cell decreases approximately by $3.6 \%$ with the increase of $0.01 \Omega$ Rs, its effect on overall efficiency is truly minor. Based on optimization, the highest efficiency of $21.66 \%$ has been achieved for $\mathrm{TiO}_{2} / \mathrm{i}-\mathrm{CH}_{3} \mathrm{NH}_{3} \mathrm{SnBr}_{3} / \mathrm{p}-\mathrm{NiO}$ solar cell $\left(V_{o c}=0.80 \mathrm{~V}, J_{s c}=31.88 \mathrm{~mA} / \mathrm{cm}^{2}\right.$ and $F F=84.89 \%$ ), which is very promising compared to $\mathrm{Pb}$-based perovskite solar cell. Nevertheless, this work successfully demonstrates the low-cost non-toxic $\mathrm{CH}_{3} \mathrm{NH}_{3} \mathrm{SnBr}_{3}$ based perovskite solar cell as a potential candidate in the photovoltaic industry.

Author Contributions: Original draft preparation, M.S.I.; conceptualization, methodology, K.S.; revising draft preparation, A.A.-K.; reviewing, M.A.I.; methodology, figure, G.M.; concept-reviewing, editing, M.S.; project administration, editing, M.A.; funding acquisition, supervision, N.A. All authors have read and agreed to the published version of the manuscript.

Funding: The authors would like to acknowledge the contribution of The National University of Malaysia through the research grant with code RS 2018-003. The authors also extend their appreciation to the King Saud University, Riyadh, Saudi Arabia for their Researchers Supporting Project number RSP-2020/34.

Data Availability Statement: The data will made available upon reasonable request to the corresponding author.

Acknowledgments: The authors gratefully acknowledge Marc Bargeman, University of Gent, Belgium, for providing the SCAPS simulation software. The authors would like to acknowledge the contribution of The National University of Malaysia through the research grant with code RS 2018-003. The authors also extend their appreciation to the King Saud University Riyadh, Saudi Arabia for their Researchers Supporting Project number RSP-2020/34. The authors duly acknowledge the publication fee related support from iRMC, Universiti Tenaga Nasional, Malaysia.

Conflicts of Interest: The authors declare no conflict of interest.

\section{Appendix A}

Table A1. Photovoltaic parameters under different defect states for $\mathrm{CH}_{3} \mathrm{NH}_{3} \mathrm{SnBr}_{3}$ perovskite solar cell. (a) amphoteric defect states. (b)ETL/Perovskite interface defect states. (c) HTL/Perovskite interface defect states.

\begin{tabular}{|c|c|c|c|c|}
\hline \multicolumn{5}{|c|}{ (a) } \\
\hline Defect Density, $10^{x} \mathrm{~cm}^{-3}$ & Voc, $\mathrm{V}$ & $J s c, \mathrm{~mA} / \mathrm{cm}^{2}$ & $F F, \%$ & Efficiency, $\%$ \\
\hline 13 & 1.09 & 31.89 & 83.87 & 29.2 \\
\hline 14 & 1.04 & 31.88 & 83.64 & 27.64 \\
\hline 15 & 0.95 & 31.85 & 80.98 & 24.5 \\
\hline 16 & 0.83 & 30.87 & 63.1 & 16.17 \\
\hline 17 & 1.85 & 11.2 & 6.98 & 1.46 \\
\hline \multicolumn{5}{|c|}{ (b) } \\
\hline Defect Density, $10^{x} \mathrm{~cm}^{-3}$ & Voc, $\mathrm{V}$ & $J s c, \mathrm{~mA} / \mathrm{cm}^{2}$ & $F F, \%$ & Efficiency, $\%$ \\
\hline 12 & 1.07 & 31.89 & 87.12 & 28.01 \\
\hline 14 & 0.99 & 31.88 & 86.15 & 26.75 \\
\hline 16 & 0.89 & 31.49 & 86.28 & 19.75 \\
\hline 18 & 0.87 & 28.89 & 85.95 & 15.88 \\
\hline 20 & 0.84 & 24.26 & 84.16 & 12.66 \\
\hline \multicolumn{5}{|c|}{ (c) } \\
\hline Defect Density, $10^{x} \mathrm{~cm}^{-3}$ & Voc, $\mathrm{V}$ & $J s c, \mathrm{~mA} / \mathrm{cm}^{2}$ & $F F, \%$ & Efficiency, $\%$ \\
\hline 13 & 0.92 & 30.23 & 87.12 & 23.6 \\
\hline 14 & 0.9 & 27.36 & 86.15 & 21.36 \\
\hline 15 & 0.88 & 24.18 & 86.28 & 18.49 \\
\hline 16 & 0.86 & 19.6 & 85.95 & 14.53 \\
\hline 17 & 0.83 & 12.89 & 84.16 & 9.04 \\
\hline
\end{tabular}




\section{Appendix B}

Table A2. $\mathrm{NH}_{3} \mathrm{SnBr}_{3}$ perovskite solar cell efficiency for different back contact metals.

\begin{tabular}{cc}
\hline Back Contact Metal & Efficiency, $\%$ \\
\hline $\mathrm{Ag}$ & 24.23 \\
$\mathrm{Fe}$ & 24.87 \\
$\mathrm{Cu}$ & 21.68 \\
$\mathrm{Cu}$ doped carbon & 25.58 \\
$\mathrm{Au}$ & 25.51 \\
\hline
\end{tabular}

\section{Appendix C}
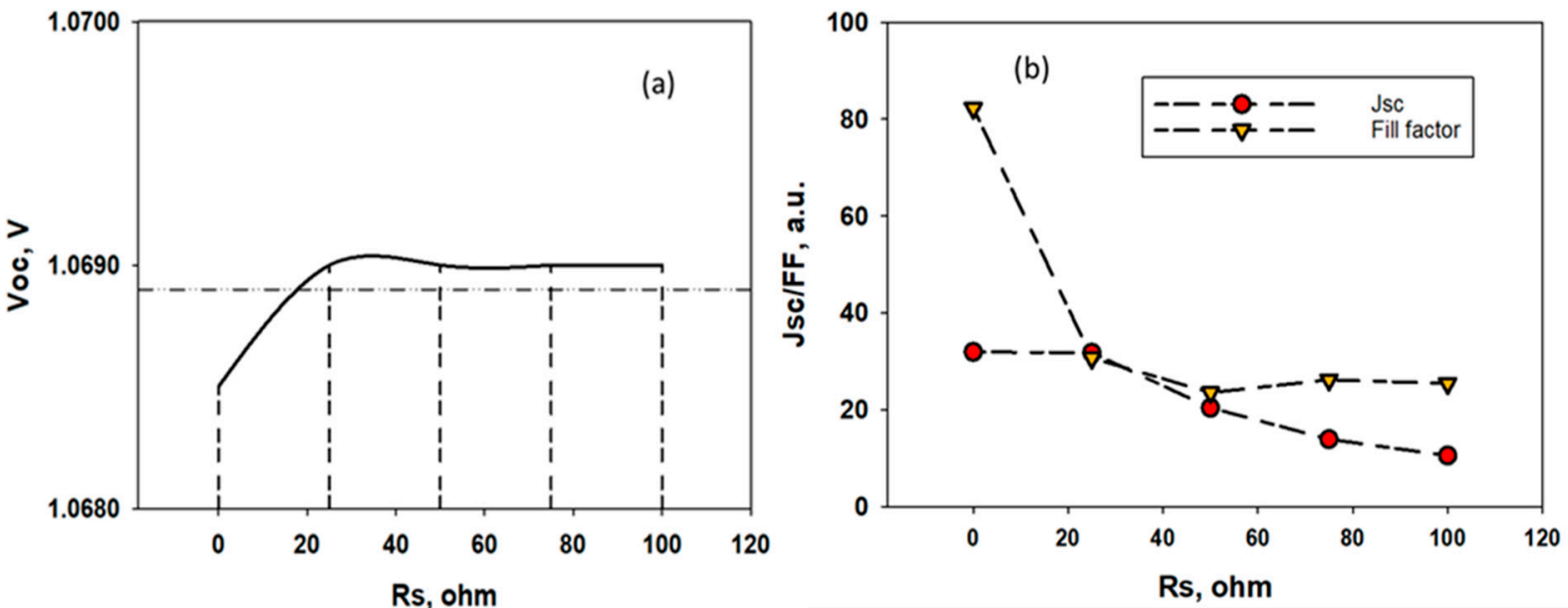

Figure A1. Impact on (a) Voc and (b) Jsc with respect to Rs of $\mathrm{CH}_{3} \mathrm{NH}_{3} \mathrm{SnBr}_{3}$ solar cell.

\section{References}

1. Kojima, A.; Teshima, K.; Shirai, Y.; Miyasaka, T. Organometal halide perovskites as visible-light sensitizers for photovoltaic cells. J. Am. Chem. Soc. 2009, 131, 6050-6051. [CrossRef]

2. Green, M.A.; Ho-Baillie, A.; Snaith, H.J. The emergence of perovskite solar cells. Nat. Photonics 2014, 8, 506-514. [CrossRef]

3. Shin, S.S.; Yeom, E.J.; Yang, W.S.; Hur, S.; Kim, M.G.; Im, J.; Seo, J.; Noh, J.H.; Seok, S.I. Colloidally prepared La-doped BaSnO3 electrodes for efficient, photostable perovskite solar cells. Science 2017, 356, 167-171. [CrossRef]

4. Burschka, J.; Pellet, N.; Moon, S.J.; Humphry-Baker, R.; Gao, P.; Nazeeruddin, M.K.; Grätzel, M. Sequential deposition as a route to high-performance perovskite-sensitized solar cells. Nature 2013, 499, 316-319. [CrossRef] [PubMed]

5. Yang, W.S.; Park, B.W.; Jung, E.H.; Jeon, N.J.; Kim, Y.C.; Lee, D.U.; Shin, S.S.; Seo, J.; Kim, E.K.; Noh, J.H.; et al. Iodide management in formamidinium-lead-halide-based perovskite layers for efficient solar cells. Science 2017, 356, 1376-1379. [CrossRef]

6. Miyata, A.; Mitioglu, A.; Plochocka, P.; Portugall, O.; Wang, J.T.W.; Stranks, S.D.; Snaith, H.J.; Nicholas, R.J. Direct measurement of the exciton binding energy and effective masses for charge carriers in organic-inorganic tri-halide perovskites. Nat. Phys. 2015, 11, 582-587. [CrossRef]

7. Chen, B.; Yang, M.; Priya, S.; Zhu, K. Origin of J-V hysteresis in perovskite solar cells. J. Phys. Chem. Lett. 2016, 7, 905-917. [CrossRef]

8. Im, J.H.; Lee, C.R.; Lee, J.W.; Park, S.W.; Park, N.G. 6.5\% efficient perovskite quantum-dot-sensitized solar cell. Nanoscale 2011, 3 , 4088-4093. [CrossRef] [PubMed]

9. Xiao, Z.; Dong, Q.; Bi, C.; Shao, Y.; Yuan, Y.; Huang, J. Solvent annealing of perovskite-induced crystal growth for photovoltaicdevice efficiency enhancement. Adv. Mater. 2014, 26, 6503-6509. [CrossRef]

10. Correa-Baena, J.P.; Abate, A.; Saliba, M.; Tress, W.; Jacobsson, T.J.; Grätzel, M.; Hagfeldt, A. The rapid evolution of highly efficient perovskite solar cells. Energy Environ. Sci. 2017, 10, 710-727. [CrossRef]

11. Saliba, M.; Matsui, T.; Seo, J.Y.; Domanski, K.; Correa-Baena, J.P.; Nazeeruddin, M.K.; Zakeeruddin, S.M.; Tress, W.; Abate, A.; Hagfeldt, A.; et al. Cesium-containing triple cation perovskite solar cells: Improved stability, reproducibility and high efficiency. Energy Environ. Sci. 2016, 9, 1989-1997. [CrossRef] [PubMed]

12. Ono, L.K.; Juarez-Perez, E.J.; Qi, Y. Progress on perovskite materials and solar cells with mixed cations and halide anions. ACS Appl. Mater. Interfaces 2017, 9, 30197-30246. [CrossRef] [PubMed]

13. Hu, C.; Bai, Y.; Xiao, S.; Zhang, T.; Meng, X.; G, W.K.N.; Yang, Y.; Chen, H.; Wong, K.S.; Yang, S. Profiling the organic cationdependent degradation of organolead halide perovskite solar cells. J. Mater. Chem. A 2017, 5, 1103-1111. 
14. Liu, X.; Yang, Z.; Chueh, C.C.; Rajagopal, A.; Williams, S.T.; Sun, Y.; Jen, A.K.Y. Improved efficiency and stability of Pb-Sn binary perovskite solar cells by Cs substitution. J. Mater. Chem. A 2016, 4, 17939. [CrossRef]

15. Ogomi, Y.; Morita, A.; Tsukamoto, S.; Saitho, T.; Fujikawa, N.; Shen, Q.; Toyoda, T.; Yoshino, K.; Pandey, S.S.; Ma, T.; et al. $\mathrm{CH}_{3} \mathrm{NH}_{3} \mathrm{Sn}_{x} \mathrm{~Pb}_{(1-\mathrm{x})} \mathrm{I}_{3}$ Perovskite Solar Cells Covering up to $1060 \mathrm{~nm}$. J. Phys. Chem. Lett. 2014, 5, 1004-1011. [CrossRef]

16. Hao, F.; Stoumpos, C.C.; Cao, D.H.; Chang, R.P.H.; Kanatzidis, M.G. Lead-free solid-state organic-inorganic halide perovskite solar cells. Nat. Photonics 2014, 8, 489-494. [CrossRef]

17. Mosconi, E.; Umari, P.; Angelis, F.D. Electronic and optical properties of mixed $\mathrm{Sn}-\mathrm{Pb}$ organohalide perovskites: A first principles investigation. J. Mater. Chem. A 2015, 3, 9208-9215. [CrossRef]

18. Im, J.; Stoumpos, C.C.; Jin, H.; Freeman, A.J.; Kanatzidis, M.G. Antagonism between Spin-Orbit Coupling and Steric Effects Causes Anomalous Band Gap Evolution in the Perovskite Photovoltaic Materials $\mathrm{CH}_{3} \mathrm{NH}_{3} \mathrm{Sn}_{1-\mathrm{x}} \mathrm{Pb}_{\mathrm{x}} \mathrm{I}_{3}$. J. Phys. Chem. Lett. 2015, 6, 3503-3509. [CrossRef]

19. Hao, F.; Stoumpos, C.C.; Chang, R.P.H.; Kanatzidis, M.G. Anomalous Band Gap Behavior in Mixed Sn and Pb Perovskites Enables Broadening of Absorption Spectrum in Solar Cells. J. Am. Chem. Soc. 2014, 136, 8094-8099. [CrossRef]

20. Zuo, F.; Williams, S.T.; Liang, P.W.; Chueh, C.C.; Liao, C.Y.; Jen, A.K.-Y. Binary-metal perovskites toward high-performance planar-heterojunction hybrid solar cells. Adv. Mater. 2014, 26, 6454-6460. [CrossRef]

21. Park, N.-G. Perovskite solar cells: An emerging photovoltaic technology. Mater. Today 2015, 18, 65-72. [CrossRef]

22. Serafettin, D.; Ahmet, N.O.; Mustafa, C.; Cebrail, O.; Merve, K. Nanostructured Solar Cells: Recent Progresses in Perovskite Solar Cells; Intech Publishers: London, UK, 2017. [CrossRef]

23. Goldschmidt, V.M. Die gesetze der krystallochemie. Naturwissenschaften 1926, 14, 477.

24. Yi, Z.; Ladi, N.H.; Shai, X.; Li, H.; Shen, Y.; Wang, M. Will organic-inorganic hybrid halide lead perovskites be eliminated from optoelectronic applications? Nanoscale Adv. 2019, 1, 1276. [CrossRef]

25. Kieslich, G.; Sun, S.; Cheetham, A.K. Solid-state principles applied to organic-inorganic perovskites: New tricks for an old dog. Chem Sci. 2014, 5, 4712. [CrossRef]

26. Li, Z.; Yang, M.; Park, J.S.; Wei, S.H.; Berry, J.J.; Zhu, K. Stabilizing Perovskite Structures by Tuning Tolerance Factor: Formation of Formamidinium and Cesium Lead Iodide Solid-State Alloys. Chem. Mater 2016, 28, 284. [CrossRef]

27. Wang, Q.; Phung, N.; Girolamo, D.D.; Vivoc, P.; Abate, A. Enhancement in lifespan of halide perovskite solar cells. Energy Environ. Sci. 2019, 12, 865 .

28. Lee, J.W.; Kim, D.H.; Kim, H.S.; Seo, S.W.; Cho, S.M.; Park, N.G. Formamidinium and Cesium Hybridization for Photo- and Moisture-Stable Perovskite Solar Cell. Adv. Energy Mater 2015, 5, 1501310. [CrossRef]

29. McMeekin, D.P.; Sadoughi, G.; Rehman, W.; Eperon, G.E.; Saliba, M.; Hörantner, M.T.; Haghighirad, A.; Sakai, N.; Korte, L.; Rech, B.; et al. A mixed-cation lead mixed-halide perovskite absorber for tandem solar cells. Science 2016, 351, 151. [CrossRef] [PubMed]

30. Kour, R.; Arya, S.; Verma, S.; Gupta, J.; Bandhoria, P.; Bharti, V.; Datt, R.; Gupta, V. Potential substitutes for replacement of lead in perovskite solar cells: A review. Glob. Chall. 2019, 3, 1900050. [CrossRef] [PubMed]

31. Burgelman, M.; Nollet, P.; Degrave, S. Modelling polycrystalline semiconductor solar cells. Thin Solid Film. 2000, 361, 527-532. [CrossRef]

32. Liu, F.; Zhu, J.; Wei, J.; Li, Y.; Lv, M.; Yang, S.; Zhang, B.; Yao, J.; Dai, S. Numerical simulation: Toward the design of high-efficiency planar perovskite solar cells. Appl. Phys. Lett. 2014, 104, 253508. [CrossRef]

33. Lin, P.; Tan, K.; Tan, J.; Wu, L.; Wang, G.; Jin, S.; Lin, Y. Device simulation of solid-state perovskite solar cells. In Proceedings of the 31st European Photovoltaic Solar Energy Conference and Exhibition, Hamburg, Germany, 14-18 September 2015.

34. Baktash, A.; Amiri, O.; Sasani, A. Improve efficiency of perovskite solar cells by using magnesium doped $\mathrm{ZnO}$ and $\mathrm{TiO}_{2}$ compact layers. Superlattices Microstruct. 2016, 93, 128-137. [CrossRef]

35. Sobayel, K.; Akhtaruzzaman, M.; Rahman, K.S.; Ferdaous, M.T.; Al-Mutairi, Z.A.; Alharbi, H.F.; Alharthi, N.H.; Karim, M.R.; Hasmady, S.; Amin, N. A comprehensive defect study of tungsten disulfide (WS2) as electron transport layer in perovskite solar cells by numerical simulation. Results Phys. 2019, 12, 1097-1103. [CrossRef]

36. Sobayel, K.; Shahinuzzaman, M.; Amin, N.; Karim, M.R.; Dar, M.A.; Gul, R.; Alghoul, M.A.; Sopian, K.; Hasan, A.K.M.; Akhtaruzzaman, M. Efficiency enhancement of CIGS solar cell by WS2 as window layer through numerical modelling tool. Sol. Energy 2020, 207, 479-485. [CrossRef]

37. Mahjabin, S.; Haque, M.M.; Sobayel, K.; Jamal, M.S.; Islam, M.A.; Selvanathan, V.; Abdulaziz, A.K.; Alharbi, H.F.; Sopian, K.; Amin, N.; et al. Perceiving of Defect Tolerance in Perovskite Absorber Layer for Efficient Perovskite Solar Cell. IEEE Access 2020, 8, 106346-106353. [CrossRef]

38. Sobayel, K.; Rahman, K.S.; Karim, M.R.; Aijaz, M.O.; Dar, M.A.; Shar, M.A.; Misran, H.; Amin, N. Numerical modelling on prospective buffer layers for tungsten di-sulfide (WS2) solar cells by scaps-1d. Chalcogenide Lett. 2018, 15, 307-315.

39. Kang, A.K.; Zandi, M.H.; Gorji, N.E. Simulation analysis of graphene contacted perovskite solar cells using SCAPS-1D. Opt. Quantum Electron. 2019, 51, 1-9. [CrossRef]

40. Stoumpos, C.C.; Frazer, L.; Clark, D.J.; Kim, Y.S.; Rhim, S.H.; Freeman, A.J.; Ketterson, J.B.; Jang, J.I.; Kanatzidis, M.G. Hybrid Germanium Iodide Perovskite Semiconductors: Active Lone Pairs, Structural Distortions, Direct and Indirect Energy Gaps, and Strong Nonlinear Optical Properties. J. Am. Chem. Soc. 2015, 137, 6804. [CrossRef] 
41. Alberi, K.; Scarpulla, M.A. Suppression of compensating native defect formation during semiconductor processing via excess carriers. Sci. Rep. 2016, 6, 27954. [CrossRef]

42. Flynn, C.; McCullough, S.; Li, L.; Donley, C.; Kanai, Y.; Cahoon, J. Passivation of nickel vacancy defects in nickel oxide solar cells by targeted atomic deposition of boron. J. Phys. Chem. C 2016, 120, 16568-16576. [CrossRef]

43. Zhu, Z.B.; Liu, Z.; Long, X.; Wei, Z.; Wang, Z.; Zhang, L.; Wang, J.; Yan, F.; Yang, S. High-permance hole-extraction layer of sol-gel-processed $\mathrm{NiO}$ nanocrystals for inverted planar per ovskite solar cells. Angew. Chem. 2014, 126, 12779-12783. [CrossRef]

44. Tang, L.; Chen, X.; Wen, T.; Yang, S.; Zhao, J.; Qiao, H.; Hou, Y.; Yang, G. A solution-processed transparent NiO hole-extraction layer for high-performance inverted perovskite solacells. Chem. Eur. J. 2018, 24, 2845-2849. [CrossRef]

45. Sun, J.; Lu, J.; Li, B.; Jiang, L.; Chesman, A.; Scully, A.; Gengenbach, T.; Cheng, Y.; Jasieniak, J. Inverted perovskitesolar cells with high fill-factors featuring chemical bath deposited mesoporous NiOhole transporting layers. Nano Energy 2018, 49, 163-171. [CrossRef]

46. Seo, S.; Park, I.; Kim, M.; Lee, S.; Bae, C.; Jung, H.; Park, N.-G.; Kim, J.; Shin, H. An ultra-thin, un-doped NiO hole transporting layer of highly efficient (16.4\%) organic-inorganic hybridperovskite solar cells. Nanoscale 2016, 8, 11403-11412. [CrossRef]

47. Anwar, F.; Sarwar Satter, S.; Mahbub, R.; Mahmud Ullah S and Afrin, S. Simulation and performance study of nanowire CdS/CdTe solar cell. Int. J. Renew. Energy Res. 2017, 7, 885-893.

48. Derry, G.N.; Kern M E and Worth, E.H. Recommended values of clean metal surface work functions. J. Vac. Sci. E Technol. A Vac. Surf. Films 2015, 33, 060801.

49. Thahab, S.M.; Hassan, H.A.; Hassan, Z. Effects of metal work function and operating temperatures on the electrical properties of contacts to n-type GaN. In Proceedings of the 2006 IEEE International Conference on Semiconductor Electronics, kuala Lumpur, Malaysia, 29 November-1 December 2006; pp. 816-819.

50. Malliaras, G.G.; Salem, J.R.; Brock, P.J.; Scott, C. Electrical characteristics and efficiency of single-layer organic light-emitting diodes. Phys. Rev. B 1998, 58, R13411. [CrossRef]

51. Sze, S.; Kwok, N. Physics of Semiconductor Devices. In Wiley Inter Science, 3rd ed.; 2007; ISBN 0471143235. Available online: https: //www.wiley.com/en-us/Physics+of+Semiconductor+Devices\%2C+3rd+Edition-p-9780470068328 (accessed on 6 March 2021).

52. Garcia-Belmonte, G.; Munar, A.; Barea, E.; Bisquert, J.; Ugarte, I.; Pacios, R. Charge carrier mobility and lifetime of organic bulk heterojunctions analyzed by impedance spectroscopy. Org. Electron. 2008, 9, 847. [CrossRef]

53. Bisquert, J.; Garcia-Belmonte, G.; Munar, A.; Sessolo, M.; Soriano, A.; Bolink, H.J. Band unpinning and photovoltaic model for P3HT: PCBM organic bulk heterojunctions under illumination. Chem. Phys. Lett. 2008, 465, 57. [CrossRef]

54. Nolasco, J.C.; Sanchez-Diaz, A.; Cabre, R.; Ferre-Borrull, J.; Marsal, L.F.; Palomares, E.; Pallares, J. Relation between the barrier interface and the built-in potential in pentacene/C60 solar cell. J. Appl. Phys. Lett. 2010, 97, 013305. [CrossRef]

55. Ray, D.; Burtone, L.; Leo, K.; Riede, M. Detection of trap charge in small molecular organic bulk heterojunction solar cells. Phys. Rev. B 2010, 82, 125204. [CrossRef]

56. Boix, P.P.; Garcia-Belmonte, G.; Munecas, U.; Neophytou, M.; Waldauf, C.; Pacios, R. Determination of gap defect states in organic bulk heterojunction solar cells from capacitance measurements. Appl. Phys. Lett. 2009, 95, 233302. [CrossRef]

57. Mingebach, M.; Deibel, C.; Dyakonov, V. Built-in potential and validity of the Mott-Schottky analysis in organic bulk heterojunction solar cells. Phys. Rev. B 2011, 84, 153201. [CrossRef]

58. Hosenuzzaman, M.; Rahim, N.A.; Selvaraj, J.; Hasanuzzaman, M.; Malek, A.A.; Nahar, A. Global prospects, progress, policies, and environmental impact of solar photovoltaic power generation Renew. Sustain. Energy Rev. 2011, 41, 284-297. [CrossRef]

59. Decock, K.; Khelifi, S.; Burgelman, M. Modelling multivalent defects in thin film solar cells. Thin Solid Films 2011, 519, 7481-7484. [CrossRef]

60. Zonno, I.; Martinez-Otero, A.; Hebig, J.C.; Kirchartz, T. Understanding mott-Schottky measurements under illumination in organic bulk heterojunction solar cells. Phys. Rev. Appl. 2017, 7, 034018. [CrossRef]

61. Niemegeers, A.; Burgelman, M. Numerical Modeling of AC-Characteristics of CdTe and CIS Solar Cells. In Proceedings of the Twenty Fifth IEEE Photovoltaic Specialists Conference, Washington, DC, USA, 13-17 May 1996; pp. 901-904.

62. Kumari, S.; Tripathi, C.; Singh, A.P.; Chauhan, D.; Shrivastav, R.; Dass, S.; Satsangi, V.R. Characterization of Zn-doped hematite thin films for photoelectrochemical splitting of water. Curr. Sci. 2006, 91, 1062-1064.

63. Abhishiktha, T. Effect of Series Resistance Increase on Fill Factor of PV Cells Extracted from Field Aged Modules of Different Climates; Arizona State University Library, Digital Repository: Tempe, AZ, USA, 2016. 